\title{
The State of the Hydrologic Source Term
}

\author{
Annie Kersting
}

December 1996

This is an informal report intended primarily for internal or limited external distribution. The opinions and conclusions stated are those of the author and may or may not be those of the Laboratory.

Work performed under the auspices of the U.S. Department of Energy by the Lawrence Livermore National Laboratory under Contract W-7405-Eng-48. 
This document was prepared as an account of work sponsored by an agency of the United States Government. Neither the United States Government nor the University of California nor any of their employees, makes any warranty, express or implied, or assumes any legal liability or responsibility for the accuracy, completeness, or usefulness of any information, apparatus, product, or process disclosed, or represents that its use would not infringe privately owned rights. Reference herein to any specific commercial products, process, or service by trade name, trademark, manufacturer, or otherwise, does not necessarily constitute or impiy its endorsement, recommendation, or favoring by the United States Government or the University of California. The views and opinions of authors expressed herein do not necessarily state or reflect those of the United States Government or the University of California, and shall not be used for advertising or product endorsement purposes.

This report has been reproduced directly from the best available copy.

Available to DOE and DOE contractors from the Orive of Scientific and Technical Information

P.O. Box 62, Oak Ridge, TN 37831

Prices available from (615) 576-8401, FTS 626-8401

Available to the public from the

National Technical Information Service

US. Department of Commerce

5285 Port Royal Rd.,

Springfield, VA 22161 


\section{The State of the Hydrologic Source Term}

Prepared for the Underground Test Area Operable Unit U.S. Department of Energy

Nevada Operations Office

Environmental Restoration Division

December, 1996

Annie Kersting

Isotope Sciences Division

Lawrence Livermore National Laboratory 


\section{Executive Summary}

Underground testing of nuclear devices that occurred between 1957 and 1992 at the Nevada Test Site (NTS) deposited substantial volumes of residual radioactive and other chemical contaminants in the subsurface. In response to concerns about the potential health hazards related to underground nuclear testing, the Underground Test Area (UGTA) Operable Unit was defined in 1992 by the U.S. Department of Energy, Nevada Operations Office to characterize and potentially remediate groundwater impacted by nuclear testing at the NTS. This program was the latest in a continuing effort that began in 1973 to characterize and remediate groundwater potentially impacted by nuclear testing.

Evaluation of groundwater contamination requires knowledge about the concentration and distribution of radionuclides in the subsurface, the processes by which they may be transported, and the surrounding hydrogeologic system. The principal agent for movement of radionuclides deposited in the subsurface is groundwater. For this reason, it is important to understand what fraction of the total radionuclide inventory in the subsurface is available for transport by groundwater, and consequently available for near- and far-field transport. This fraction is called the hydrologic source term and consists of radionuclides that are present as dissolved, colloidal and/or surface species in the cavity-chimney and the vicinity of the cavity.

A multi-faceted scientific approach has been required to address the complex nature of radionuclide contamination in the subsurface at the NTS. This report summarizes our current understanding of the hydrologic source term and highlights research areas where further knowledge is critical to development of a defensible hydrologic transport model. Current findings include the following:

- To date, the majority of the radionuclides have not migrated far from the individual test cavities. The initial heterogeneous distribution of radionuclides is not easily homogenized by movement of groundwater in the cavities. Yet, the maximum extent of radionuclide distribution as a result of groundwater transport in the far-field is not well known.

- The conservative elements that are dissolved as neutral species $\left({ }^{3} \mathrm{H},{ }^{85} \mathrm{Kr}\right)$ or anions $\left({ }^{36} \mathrm{Cl},{ }^{99} \mathrm{Tc},{ }^{129} \mathrm{I}\right)$ migrate with groundwater without appreciable sorption, yet our understanding of how and to what extent cationic radionuclides migrate and at what rate is less clear.

- The majority of the residual activity after a nuclear detonation in the subsurface is trapped in the melt glass. Dissolution of the melt glass and 
release of the radionuclides will probably occur slowly. However, we have not yet applied kinetic models of dissolution to the problem, nor do we know if measured activities of specific radionuclides in the groundwater are colloidally bound, dissolved or sorbed to secondary mineral phases.

- A substantial fraction of the total radioactivity in groundwater can be associated with sorption on colloids, but we do not know the effects of long term transport.

- A large fraction of the total radioactivity at the NTS is in the vadose zone. We do not know whether this is moving downward into the saturated zone. 


\section{Introduction}

The Underground Test Area (UGTA) Operable Unit was defined by the U.S. Department of Energy, Nevada Operations Office to characterize and potentially remediate groundwater impacted by nuclear testing at the Nevada Test Site (NTS). Between 1955 and 1992, 828 nuclear devices were detonated underground at the NTS (DOE, 1994) (Fig. 1). Approximately one third of the nuclear tests were detonated at or below the standing water table and the remainder were located above the water table in the vadose zone. As a result, the distribution of radionuclides in the subsurface and, in particular, the availability of radionuclides for transport away from individual test cavities are major concerns at the NTS.

The UGTA program initially directed its efforts toward understanding the regional hydrology (groundwater flow paths and flow rates) at the NTS. Recently, the program expanded to include characterization of impacted groundwaters within the near-field environment - that is, within several cavity radii $(<\sim 500 \mathrm{~m})$ of working (firing) point of selected underground nuclear tests. The approach taken is to carry out field-based studies of both groundwater and host rocks within the near-field in order to develop a detailed understanding of the present-day concentration and spatial distribution of constituent radionuclides. Understanding the current distribution of contamination within the near-field and the conditions under and processes by which the radionuclides were transported makes it possible to predict future transport behavior.

The results of these studies will be integrated with archival research, experiments and geochemical modeling for complete characterization. Geochemical models of the near-field environment will provide evaluation of the potential transport of radionuclides in groundwater away from nuclear test cavities. This will allow construction of a defensible hydrologic transport and risk assessment model applicable on a regional scale.

Complete characterization of subsurface contamination must include quantification of the total radiologic source term and the hydrologic source term. The total radiologic source term is the amount of radioactivity remaining in the subsurface summed for all the 828 individual underground nuclear tests. The hydrologic source term is the fraction of the total radiologic source term that is available for transport by groundwater, and consequently available for near- and far-field transport. This fraction consists of radionuclides that are present as dissolved, colloidal and/or surface species in the cavity-chimney waters and the vicinity of the cavity (Fig. 2). The understanding of how and what radionuclides can be transported in the subsurface combined with knowledge of groundwater flow rates is critical to ultimately determining the environmental risk due to underground nuclear testing at the NTS. 
The purpose of this report is to summarize our current understanding of the:

- distribution of the radionuclides in the subsurface at the NTS,

- relation between the radiologic source term and the hydrologic source term,

- factors that influence radionuclide transport,

- important geochemical processes that control radionuclides in groundwater, and

- potential for radionuclide migration at the Nevada Test Site extrapolated from laboratory and field investigations.

This report relies heavily on previously published data, and readers are encouraged to consult the referenced publications for a more detailed treatment of specific topics.

\section{Distribution of Radionuclides in the Subsurface}

\section{Explosive Phenomenology}

This section presents a brief description of the explosive phenomenology of an underground nuclear detonation in order to highlight the complexity and heterogeneity of the subsurface environment following a nuclear test. A more thorough treatment can be found in reports by the Office of Technology Assessment (1989) and Smith (1993, 1995a). During the detonation of a nuclear device, the rock immediately surrounding the device vaporizes and expands as a plasma. Temperatures exceed $1 \times 10^{6} \mathrm{~K}$ and pressures exceed 7 Mbar. Approximately 70 metric tons of rock is vaporized for every kiloton of yield (Smith, 1993). Within the first few milliseconds, a compressional shock wave travels radially several hundred meters beyond the initial cavity from the working point and melts the adjacent wall rock. Cavity gases expand beyond the initial cavity. As the temperatures decrease, the refractory material condenses on the walls of the standing cavity and coalesces as melt at the bottom. Approximately 700 to 1300 metric tons of rock are melted for every kiloton of yield (Borg et al., 1976). As the gases continue to cool and condense, the cavity collapses and creates a rubble zone, or chimney, above the cavity. As the cavity begins to collapse some of the volatile and gaseous radionuclide species are forced upward where they condense and are deposited on the surface of the rubble and in fractures. As a result of the blast, the rock surrounding the cavity is pervasively fractured and, together with the cavity and chimney, has substantially greater porosity than the initial host rock (Borg et al., 1976).

Although the explosion phenomena for all successful underground nuclear tests is similar, different device designs and yields, set in different rock types 
(e.g. alluvium, volcanic) and at different burial depths relative to the standing water table make each nuclear test unique. Underground nuclear tests ranged in yield from less than $1 \mathrm{kt}$ to detonations in excess of $1000 \mathrm{kt}$ (DOE, 1994). The total volume of rock affected ranges significantly from test to test. For example, the STALWORT event was a $85 \mathrm{kt}$ detonation fired at a depth of 564 $\mathrm{m}$ in volcanic tuff. It produced a cavity approximately $104 \mathrm{~m}$ in diameter and a chimney region extending to the surface (Borg et al., 1976). The cavity of much larger tests can be estimated by using the scaling factor developed by Hudson et al. (1981) and given in equation 1 (Smith, 1995c).

$$
R_{c}=\frac{70.2 W^{1 / 3}}{(\rho h)^{1 / 4}}
$$

$R_{c}$ is the cavity radius, in meters, $W$ is the yield in kilotons, $\rho$ is the average overburden density in $\mathrm{gm} / \mathrm{cm}^{3}$, and $\mathrm{h}$ is the working point in meters from the surface. For an event with an $800 \mathrm{kt}$ yield in the same host rock and the same depth of burial as STALWORT, the cavity would be approximately 195 $\mathrm{m}$ in diameter. The extent to which the surrounding rock is fractured is also a strong function of yield and strength of the rock. Rock outward of 1.3 cavity-radii is intensely pulverized. Up to a distance of 2 cavity-radii the rock is pervasively fractured. At distances up to 5 cavity-radii fractures occur, but are more widely spaced. Offsets on preexisting faults at distances up to 11 cavity-radii have been observed (Laczniak et al., 1996). The extent of fracturing, thermal perturbations, and most importantly, the residual inventory of radioactivity and its initial distribution in the subsurface are different for each individual event.

\section{Radiologic Source Term}

In the aftermath of a nuclear test, tritium, actinides, fission and activation products and non-radioactive metals are deposited in the subsurface. The radiologic source term inventory for 46 radionuclides with half lives in excess of ten years was compiled for each nuclear test fired beneath the NTS (Goishi et al., 1994). A separate report contains an inventory of the 46 radionuclides for each of five sub-areas at the NTS (Bowen et al., 1994). These reports are currently classified. Efforts are underway to declassify the latter which includes five sub-area radionuclide totals for the NTS. For a detailed discussion of the approach used in calculating the radionuclide source term, the reader is referred to an unclassified report by Smith (1995b).

The residual radionuclide inventory from a nuclear test is strongly dependent on the design of the specific device employed. The largest concentration of residual tritium, $\left({ }^{3} \mathrm{H}\right)$, is produced by the burning of $\mathrm{Li}$ weapon fuels. Depending on design, devices can either produce or consume ${ }^{239} \mathrm{Pu}$. The nature of the nuclear test program insured it is difficult to propose an 
"average" device or an "average" per-event radiologic source term for the Nevada Test Site. Area source terms are independent of the number of tests fired. Therefore, source term information on smaller sub-divisions of the NTS, coupled with hydrogeologic data will allow more accurate assessment of the potential transport of radionuclides in groundwater away from nuclear test cavities. For this reason, declassification actions are being pursued with urgency.

\section{Converting the Radiologic Source Term to the Hydrologic Source Term}

The total activity in the subsurface at the NTS is estimated to be greater than $10^{8}$ curies (decay corrected to $1 / 1 / 94$ ). This is the total radiologic source term. Not all the radionuclides are equally available for transport; only a subset of the total radiologic source term will comprise the hydrologic source term. Due to the energy release during an underground nuclear explosion, the initial spatial and chemical distribution of radionuclides in the subsurface is both complex and heterogeneous. In order to convert the total radiologic source term into a hydrologic source term it is necessary:

- to know the initial physical distribution of radioactivity after a nuclear test,

- what chemical fraction is incorporated into the melt glass,

- what chemical fraction is surface deposited onto the surrounding rubble,

- what portion of the total radiologic inventory is near or below the water table, and

- to understand how this source term changes with time as the nuclides decay.

In addition, the hydrologic source term will evolve chemically in response to the interaction between the groundwater and host rock resulting in the dissolution of mineral phases and melt glass and precipitation of secondary minerals.

\section{Physical Distribution of the Radionuclide Inventory}

Figure 2 is a schematic flow chart relating the radionuclide source term to the hydrologic source term. The initial distribution of radionuclides can be grouped into 3 areas:

- a fraction of the radionuclides will be incorporated into the melt glass during initial cooling of the cavity,

- a fraction of the radionuclides will be deposited on the rubble and along fractured surfaces, both within and outside the cavity, and

- a very small fraction of the gaseous radionuclides will escape to the atmosphere. 
Although the majority of the melt coalesces and solidifies at the bottom of the detonation cavity, some melt is deposited in the upper regions of the cavitychimney area. Samples of chimney rubble are often populated by small pieces of glass that are emplaced when the melt is splashed by in-fall of chimney material during cavity collapse.

Nimz and Thompson (1992) report on nine locations where radionuclides were detected in the saturated zone and were traceable back to a specific underground event. They concluded that for five locations, radionuclides were deposited outside the detonation cavity during the early-time detonation of the nuclear test as a result of gaseous (prompt) injection through fractures and not as a result of groundwater transport via groundwater. In these studies the presence of impacted groundwaters outside the test cavities suggests only a minimum horizontal distance for radionuclide transport. Impacted waters were collected at $350 \mathrm{~m}$ horizontally away from the zero point of the ALEMAN event (Thompson and Gilmore, 1991), $320 \mathrm{~m}$ from the LATIR event, and $122 \mathrm{~m}$ (60 m outside the cavity) from the BILBY event (Nimz and Thompson, 1992). Radionuclides were also detected outside the INGOT cavity, an event detonated in the vadose zone in the absence of groundwater. Radionuclides were measured on solid samples collected $10 \mathrm{~m}$ horizontally outside the cavity as well as in water samples taken from a well completed below the cavity. Smith et al. (1996) was able to show that at INGOT gaseous transport of radionuclides also occurs during the later stages of the nuclear event, resulting in severe fractionation of specific gaseous species.

The vertical extent of radionuclide deposition was evaluated during a study of the HYRAX event. In this study, ${ }^{137} \mathrm{Cs}$ was found to have ascended approximately 5 cavity radii through the HYRAX collapse chimney (Smith and Thompson, 1996). This study, in conjunction with studies of lateral radionuclide deposition, demonstrates that radionuclides can be deposited considerable distances vertically as well as horizontally from the working point.

As a result of a nuclear detonation, small amounts of radioactive gas may be released to the atmosphere. Releases of radioactivity can occur as a result of a failure to contain the detonation, late-time seeping of gases diffusing through pore spaces, or an intentional purging of a tunnel. Between 1971 and 1988 the total activity released to the atmosphere at the NTS was $5.4 \times 10^{4} \mathrm{Ci}$ (Office of Technology Assessment, 1989). The only major release to the atmosphere from an underground shot prior to 1971 was the BANEBERRY event. In 1970, BANEBERRY released $6.7 \times 10^{6} \mathrm{Ci}$ (Office of Technology Assessment, 1989). The activity released to the atmosphere through 1988 has an insignificant effect on the calculated radiologic source term $(1 / 1 / 94)$ due to the 
extremely short half lives of many of the gaseous radionuclides (e.g., ${ }^{37} \mathrm{Ar} \mathrm{t}_{1 / 2}$ $=35$ days, ${ }^{131} \times \mathrm{Xe}_{1 / 2}=11.9$ days, ${ }^{133} \mathrm{I}_{1 / 2}=9$ seconds).

\section{Chemical Distribution of the Radionuclide Inventory}

The melt glass entrains the refractory radionuclides, those with higher boiling points. These include the rare earths (e.g., $\mathrm{Ce}, \mathrm{Sm}, \mathrm{Eu}$ ), alkaline earths (e.g. $\mathrm{Mg}, \mathrm{Sr}, \mathrm{Ba}$ ), actinides (e.g., $\mathrm{Am}, \mathrm{Pu}$ ) and $\mathrm{Zr}$. In addition, many of the fission and neutron activation products $\left({ }^{54} \mathrm{Mn},{ }^{60} \mathrm{Co},{ }^{99} \mathrm{Tc},{ }^{106} \mathrm{Ru},{ }^{125} \mathrm{Sb},{ }^{137} \mathrm{Cs}\right.$, and ${ }^{147} \mathrm{Pm}$ ) are also found in the melt glass (Borg, 1975; Hoffman et al., 1977). These radionuclides are structurally incorporated into the glass matrix and are not immediately available for transport with groundwater. As the melt glass becomes saturated by groundwater, it is susceptible to leaching and alteration resulting in the slow release of radioactivity into the groundwater. The rate of this process is a function of the initial composition of the glass, oxidation state, surface area, composition of the groundwater, $\mathrm{pH}$, and temperature.

Many radionuclides are fractionated during a nuclear explosion and are incorporated in the melt glass as well as deposited on the surface of the rubble material. The radionuclides that are more volatile have lower boiling points and remain as gases longer than the refractory species. The more volatile a radionuclide the less likely it will be incorporated into the melt glass. Borg (1975) analyzed melt glass collected at various distances from the bottom of the cavity. She found that the highest concentrations of the semi-volatile species, such as, ${ }^{106} \mathrm{Ru}$ and ${ }^{125} \mathrm{Sb}$, were in the melt glasses located the farthest away from the bottom of the cavity. Species that are more volatile include the alkali metals (e.g. $\mathrm{Na}, \mathrm{K}, \mathrm{Rb}, \mathrm{Cs}$ ), $\mathrm{Ru}, \mathrm{U}, \mathrm{Sb}, \mathrm{Tc}, \mathrm{I}$, and ${ }^{3} \mathrm{H}$.

Steam and non-condensable gases, such as, $\mathrm{CO}_{2}$, air and $\mathrm{H}_{2}$ may act as carriers for the more volatile species, transporting them significant distances from the cavity. The ultimate distribution of the radionuclide inventory for the more volatile species (e.g., $\left.{ }^{3} \mathrm{H},{ }^{106} \mathrm{Ru},{ }^{125} \mathrm{Sb},{ }^{129} \mathrm{I}\right)$ may depend on the capacity of the non-condensable gases to carry radionuclides through fractures away from the cavity. This further increases the heterogeneity of the radionuclide distribution.

In addition to the semi-volatile species, long-lived, non-condensable radiogenic gaseous species (e.g., $\mathrm{Ar}, \mathrm{Xe}, \mathrm{Kr}$ ) have the potential to travel farther away from the zero point. ${ }^{137} \mathrm{Xe}$ is the parent radionuclide of ${ }^{137} \mathrm{Cs}$ and has a half-life $\left(t_{1 / 2}\right)$ of 3.8 minutes. During the first minute(s) of a nuclear detonation (early-time), the noble gas ${ }^{137} \mathrm{Xe}$ is transported away from the working point before it has time to decay to ${ }^{137} \mathrm{Cs} .{ }^{137} \mathrm{Cs}$ is found deposited on the fracture surfaces away from the working point as a result of the transport properties of its parent (see Smith et al., 1996). A similar distribution is noted 
for ${ }^{90} \mathrm{Sr}$, produced by the decay of the short-lived noble gaseous precursor ${ }^{90} \mathrm{Kr}$ with a half-life of 32.3 seconds.

The distribution of the longer lived radioactive species after a nuclear detonation also depends on the distribution and chemical behavior of the parent isotope. The distribution of radionuclides is complex and for those species that partition between both the melt glass and the rubble our current understanding of their initial spatial behavior is limited.

Borg (1975) studied the distribution of radioactivity between melt glass and rubble. Evaluating samples from the PILEDRIVER event, a nuclear detonation in granitic rock, Borg concluded that greater than $60 \%$ of the radioactivity is incorporated in the melt glass. During the first few seconds of a nuclear detonation, as much as $90 \%$ of the radionuclides are partitioned into the melt, but many of these nuclides are very short lived, on the order of microseconds to minutes, and thus, with time the percentage of radioactivity in the melt decreases relative to the activity associated with the surrounding rocks.

The original heterogeneous distribution of the radionuclides appears to remain intact for many years. Thompson (1996) analyzed a series of core samples collected below the water table 13 years after the BASEBALL event and found extreme ranges in the concentrations of radionuclides from samples collected in close vertical and horizontal proximity. This observation suggests that all the radionuclides, including ${ }^{3} \mathrm{H}$, are not readily homogenized by subsequent interaction with in-filling groundwaters.

\section{Radiologic Source Term Near or Below the Static Water Level}

Approximately one-third of all the underground tests were detonated near or below the water table (Laczniak et al., 1996). The fraction of the total radiologic source term that is near or below the water table and thus available to groundwater, has been calculated. Smith (1995b) reports the total inventory of selected fission, actinide radionuclides and tritium for those events fired below or near the water table at the NTS. These values, reported in curies (Ci) and decay corrected to $1 / 1 / 94$, are reproduced below.

Table 1

\begin{tabular}{lllllll}
$3_{\mathrm{H}}$ & ${ }^{85} \mathrm{Kr}$ & ${ }^{137} \mathrm{Cs}$ & ${ }^{99} \mathrm{Tc}$ & ${ }^{235} \mathrm{U}$ (device) & ${ }^{239} \mathrm{Pu}$ & $\mathrm{U}$ (natural) \\
\hline$\sim 10^{7}$ & $\sim 10^{5}$ & $\sim 10^{6}$ & $\sim 10^{2}$ & $\sim 4$ & $\sim 10^{4}$ & $\sim \times 10^{1}$
\end{tabular}

Tritium is the most abundant radionuclide produced by underground testing. greater than $95 \%$ of the tritium produced occurs as molecular HTO (tritiated water). Due to its abundance and the fact that HTO is an excellent tracer of 
groundwater flow, the fate of ${ }^{3} \mathrm{H}$ in groundwater has largely been the focus for evaluating risk to human health and the environment. Yet, the abundance of a radionuclide is not directly proportional to the potential risk to human health. For example, although there is significantly more ${ }^{3} \mathrm{H}$ in the subsurface than ${ }^{239} \mathrm{Pu},{ }^{3} \mathrm{H}$ poses less of a health risk than $\mathrm{Pu}$. Proposed regulatory requirements (Federal Register 40 CFR 141 and 142, 1991, 1996) for safe community drinking water limit the annual dose equivalent for humans to $4 \mathrm{mrem} / \mathrm{y}$. To receive a $4 \mathrm{mrem} / \mathrm{y}$ dose limit via consumption of 2 liters per day, an adult would have to drink water containing $85,600 \mathrm{pCi} / \mathrm{L}$ of ${ }^{3} \mathrm{H}$. In contrast, drinking water containing just $0.084 \mathrm{pCi} / \mathrm{L}$ of $239,240 \mathrm{Pu}$ would result in the same annual dose equivalent (Adams, 1996).

Table 2 is a list of radionuclides that were ranked in groups from the highest to lowest risk based on a specific dose received from ingestion (Adams, 1996).

Highest Risk

Table 2

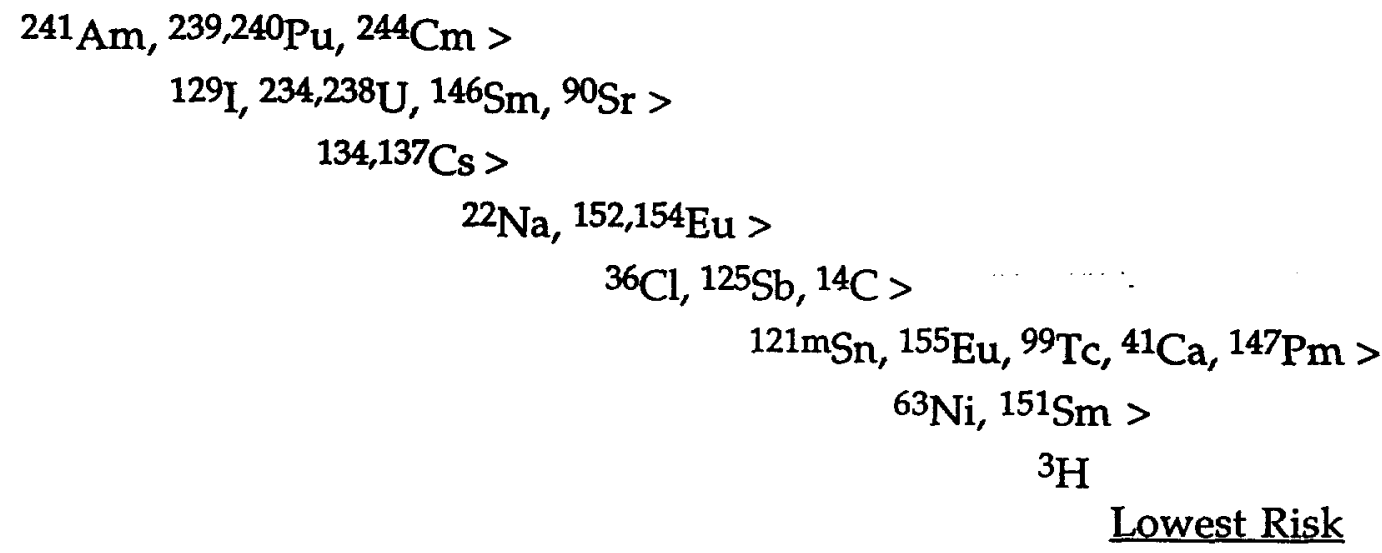

Clearly, a person can ingest significantly more ${ }^{3} \mathrm{H}$ in drinking water than $239 / 240 \mathrm{Pu}$ before reaching the regulatory limit. Therefore, it is important to couple risk with inventory and decay in evaluating the potential deleterious health effects associated with radionuclide migration.

In evaluating risk, it is also important to understand how rapidly individual radionuclides can be transported. Even though ingesting ${ }^{239} \mathrm{Pu}$ is significantly more hazardous than ingesting the same amount of ${ }^{3} \mathrm{H}$, these radionuclides are not equally available for transport in the subsurface. Tritium is far more mobile in groundwater than ${ }^{239} \mathrm{Pu}$ and as a result is easily transported away from test cavities. The relationship between the initial concentration, rate of decay, and transport properties of the specific radionuclides ultimately determines the potential hazard to human health. 


\section{Evolution of the Source Term}

The radiologic inventory will evolve with time as a result of radioactive decay. Radioactive decay is mathematically described by the exponential function:

$$
A=A_{0} e^{-\lambda t}
$$

where $A$ is the activity at time $t, A_{0}$ is initial activity at time $t=0 ; t$ is decay time from $t=0$ and $\lambda$ is the decay constant. The isotopes that dominate the source term today will be different than those radionuclides that are of concern in the future. This observation is shown schematically in Figure 3 where the contribution of the total source term from tritium, fission products and the actinides is plotted against time. For example, for the first 100-120 years, the amount of radioactivity from ${ }^{3} \mathrm{H}$ below the water table dominates the source term. Due to the relatively short half-life of ${ }^{3} \mathrm{H}\left(t_{1 / 2}=12.3\right.$ years), its contribution to the source term declines rapidly. After 200 years (starting from 1994), ${ }^{3} \mathrm{H}$ has decayed to the point where it no longer contributes significantly to the radiologic source term and actinides and long-lived fission products dominate. The change in the radiologic source term with time is a critical factor in any model that evaluates risk over a time period longer than 100 years.

\section{Factors that Influence Transport of Radionuclides in Groundwater}

For an event detonated below the static water level, groundwater which is vaporized and displaced by the explosion will eventually begin to fill the cavity and overlying rubble. This hot groundwater will begin to react with the fused and pulverized explosive debris. With time, the system will return to ambient temperature and rock-water reactions will continue but at a slower rate. Radionuclides that were incorporated into the melt glass will be released slowly as the glass is dissolved by moving groundwater. In contrast, radionuclides that are deposited on the surface of the host rock are readily available to groundwater and may be incorporated more rapidly. The mobility of radionuclides in groundwater, following their release from the subsurface at a nuclear test cavity, is governed by the flow rate, groundwater chemistry, solid particles (particulates and colloids), and the geochemical behavior of the radionuclides.

The ultimate control for radionuclide migration away from the cavity regions is the rate of groundwater flow. Clearly, if the hydrologic gradient is low, the flow away from the cavity will be slow and potential transport of radionuclides to the near-field will be minimized. Estimates of groundwater flow rates at the NTS are highly variable and range from 2 to $183 \mathrm{~m} / \mathrm{y}$ 
(Winograd and Thordarson, 1975). This large range in flow rates reflects the fact that groundwater flowing beneath the NTS passes through variably fractured and porous rock types, each having a different permeability. This results in a complex hydrologic system at the NTS. Although progress has begun in defining flow-paths and flow-rates using a combination of field measurements, 3-D finite difference modeling and isotopic analysis, critical understanding of the hydrologic flow system at the NTS is far from understood (e.g., Davisson et al., 1994, Chapman et al., 1996).

Whether or not radionuclides are transported with groundwater depends on the leach (or dissolution) rates between the glass, debris rubble and water. The release function, or rate at which the radionuclides are both leached from the rock matrix and dissolved from the melt glass, is a complex physicochemical interaction that depends on the surface area available for rock-water interactions, temperature, composition and $\mathrm{pH}$ of the groundwater, and chemical characteristics of the radionuclide species. Modeling the release function is further complicated by the extreme heterogeneity in the spatial distribution of the radionuclides among the melt glass and rubble debris.

\section{Geochemical Processes that Control Radionuclides in Groundwater}

Once radionuclides are leached from melt glass or rubble and are in the groundwater, their concentration and transport are controlled by the following complex processes, 1) precipitation, 2) aqueous complexation, 3) sorption, and 4) colloid formation. Radionuclides can react with various components of the groundwater, host rock and groundwater colloids to form solution species and/or insoluble phases. The degree to which these processes influence the transport of radionuclides is strongly dependent on the speciation of the radionuclides in solution. The speciation is a function of oxidation state, $\mathrm{pH}$, groundwater composition, and temperature.

Precipitation of radionuclides can occur if the concentration of a radionuclide in solution exceeds its solubility in the groundwater and forms a solid phase. Precipitation of a solid phase will reduce the concentration of the specific nuclide in solution and will have a retarding effect on release and transport rates.

Complexation occurs when naturally occurring inorganic and/or organic ligands form aqueous complexes with nuclides or other species in solution. Although inorganic ligands such as hydroxide, carbonate, or sulfate can form complexes with actinides, naturally occurring organic ligands have a much stronger capacity to complex actinides (Silva and Nitsche, 1995). Complexation of radionuclides increases their concentration in solution and will increase release and transport rates. 
Radionuclides in solution can attach themselves reversibly or irreversibly to mineral or rock surfaces. This process whereby solutes are removed from a solution to a solid surface is described by the term sorption. Sorption is a general, non-mechanistic term that refers to interactions between the solid phase and the solute in the liquid phase that leads to adsorption or desorption. The sorption of radionuclides onto the host mineral phase is a strong retarding mechanism for transport.

Sorption is described quantitatively by experimentally measured $R_{d}$ values. The $R_{d}$, or distribution ratio, is a macroscopic expression of the distribution of elements between the solid and liquid phases. It relates the ratio of the concentration in the solid $\left(C_{s}\right)$, and the concentration in the liquid $\left(C_{l}\right)$ for a given element, such that, $R_{d}=\left(C_{s} / C_{1}\right)$. This formulation is not a thermodynamic quantity and does not imply equilibrium as does the distribution coefficient, $\left(K_{d}\right)$. An increase in surface area will increase $R_{d}$.

Finally, the radionuclides can either sorb to or form colloidal sized particles. Colloids are small particulates that range in size from 1-0.001 $\mu \mathrm{m}$ in diameter, that naturally occur in groundwater. Because of their small size, they are capable of being transported significant distances by groundwater. The concentration and composition of colloids in groundwaters will depend on the associated host rock. Colloids are commonly composed of fragments of the host rock minerals, clays, organic matter, or a combination of these constituents. Depending on their size and charge relative to the surrounding rock, colloids can move either slower or faster than average groundwater (Silva and Nitsche, 1995). If colloids have the same charge as the host rock, they are repelled and their relative velocity is enhanced.

The role of colloids in facilitating the transport of radionuclides is not well understood; however, there are studies that suggest actinides, which have been shown to strongly sorb to rock particles, can be transported significant distances in the subsurface (Rawson et al., 1991). At a mixed-waste facility, Pu migrated a minimum of $34 \mathrm{~m}$ vertically in the subsurface beneath stored waste containers (Rawson et al., 1991). Because of its extremely low solubility ( $<1 \times 10^{-16}$ molal, Rawson et al., 1991), environmental levels of Pu most likely migrated as colloids.

Dissolution, precipitation, complexation, sorption, and colloidal transport are all processes that influence the transport of radionuclides in groundwater. Previous work at the NTS and elsewhere has yielded insight on how radionuclides behave under saturated conditions. The following section highlights our current understanding of radionuclide migration in the saturated zone and how these processes influence the hydrologic source term. 


\section{Radionuclide Migration Based on Insights from Previous Laboratory and Field Investigations}

\section{Laboratory Experiments}

Over time, the melt glass in contact with groundwater will partially dissolve, release some of the trapped radionuclides, and form both non-crystalline and crystalline secondary solids. Glass reactions are complex and depend on both the initial glass composition and the chemistry of the groundwater. Bourcier (1994) and Bates et al. (1982) carried out experiments on borosilicate $\mathrm{B}_{2} \mathrm{O}_{3} \sim 5$ 10 weight\%) nuclear waste glass and showed that the major processes occurring during glass dissolution include: 1) water diffusion into the glass, 2) subsequent alkali ion exchange, 3) formation of diffusion and gel layers on the contact surface between the glass and water, and 4) re-precipitation of released elements to form secondary phases. Clays and zeolites are common secondary phases.

A number of leaching studies on nuclear melt glass and rock debris have been carried out to determine the rate at which melt glass reacts and releases radionuclides (e.g. Wolfsberg, 1978; Ramspott et al., 1979; Failor et al., 1983). A thorough review of experimentally derived leaching rates for both melt glass and rubble was compiled by Smith (1993). Experimentally determined leach rates of radionuclides from nuclear melt glass arranged from the highest to lowest are as follows: ${ }^{22} \mathrm{Na}>{ }^{124} \mathrm{Sb}>{ }^{137} \mathrm{Cs}>{ }^{125} \mathrm{Sb}>106 \mathrm{Ru}>54 \mathrm{Mn}>144 \mathrm{Ce}>{ }^{95} \mathrm{Zr}$ (Ramspott et al., 1979). Glass with a smaller size fraction (higher surface area), has a higher leach rate than larger size glass fractions (Wolfsberg, 1978). In another set of experiments that lasted 420 days, measured average leach rates ranged from $1 \times 10^{-2} \mathrm{~g}$-glass $/ \mathrm{m}^{2}$ day for ${ }^{22} \mathrm{Na}$ to $1 \times 10^{-6} \mathrm{~g}$-glass $/ \mathrm{m}^{2}$ day for ${ }^{54} \mathrm{Mn}$ (Failor et al., 1983). Average leaching rates arranged in decreasing order are: ${ }^{131}$ I (leach rate: $9 \times 10^{-3}$ ) $>129,133 \mathrm{Te}>124,127 \mathrm{Sb}>{ }^{137} \mathrm{Cs}>237 \mathrm{U}>58,60 \mathrm{Co}>$ $103,106 \mathrm{Ru}>141,144 \mathrm{Ce}>{ }^{44} \mathrm{Mn}>95 \mathrm{Zr}>239,240 \mathrm{Pu}$ (leach rate: $3 \times 10^{-7}$ ) (Smith, 1983). During the 420 day experiment, the majority of the samples lost less than $1 \%$ of the original activity of a given radionuclide. Although the results are from a single experiment, they demonstrate that the radioactivity from the melt glass was released slowly. During the course of the experiments, the leach rates did not reach steady state, and therefore, caution should be used when extrapolating these results beyond the duration of the experiment.

Wolfsberg (1978) evaluated leach rates of radionuclides in rubble debris and melt glass, and found that the volatile species, I, Mo and Sb had the highest leach rates from tuff, alluvium and rhyolite. With the exception of 131I, the leach rates for each specific radionuclide were higher in rubble debris than for melt glass. Failor et al. (1983) concluded that leach rates of radionuclides from both melt glass and rubble debris are slow. In excess of $98 \%$ of the radionuclides remain in the glass or on debris surfaces even after a year 
(Failor et al., 1983). Again, as equilibrium was not obtained during the experiments, caution should be exercised when extrapolating the leach rates beyond the length of each experiment ( 1 year) and beyond the physical and chemical conditions of the experiment.

One of the problems in extrapolating the measured dissolution rates of melt glass to a release function is that the glasses are heterogeneous and leaching will occur preferentially from areas most susceptible to dissolution. Glass compositions with higher $\mathrm{Ca}$ and $\mathrm{K}$ concentrations will have higher dissolution rates than glasses with greater abundances of $\mathrm{Al}$ and $\mathrm{Si}$ (Smith, 1993).

Previous experiments sponsored by LLNL and LANL did not attempt to evaluate the mechanisms for dissolution nor the processes involved in migration (i.e. colloidal, dissolved). Understanding the mechanism for dissolution would improve our ability to predict leaching rates beyond the experimental time period.

Sorption rates are strongly controlled by mineralogy, surface area, groundwater composition, temperature and oxidation state. Relative comparisons can be inferred from experiments sponsored by LLNL and LANL using different sorbing media. In general, retardation ratios $\left(R_{d}\right.$ 's) can be arranged from the highest to the lowest as follows: $\mathrm{Pu}>\mathrm{Cs}>\mathrm{Sr}>\mathrm{Tc}$ (Coles et al., 1980): The actinides are all strongly sorbed to solid material. The rare earths $(\mathrm{Eu}, \mathrm{Ce}, \mathrm{Y})$ are more strongly sorbed than $\mathrm{Sb}, \mathrm{Sr}, \mathrm{Ru}$ and $\mathrm{U}$.

\section{Field Experiments}

Since the 1970's, LLNL and LANL have collected and analyzed waters from saturated nuclear event cavities as part of a program to measure and monitor radionuclides in groundwater. This program is part of a monitoring program currently administered by the Hydrologic Resources Management Program (HRMP). Due to cavity collapses and well pluggings, fewer than 20 of approximately 300 saturated nuclear event cavities are available for sampling (Nimz and Thompson, 1992, Laczniak et al., 1996). Smith et al. (1996) compiled data on samples collected and analyzed by LLNL from eleven saturated cavities from the 1970's to present (Fig. 4). Significant differences in sampling protocol exist. Some samples were collected using 2 liter bailers and some wells were pumped prior to sampling. Some samples were filtered before analysis and some were not. Not all radionuclides of interest were analyzed for each fluid sample. As a result of the differences in sampling techniques, it is difficult to directly compare analyses from different cavities. Yet, having recognized these limitations, important information can still be obtained from cavity waters on the occurrence of specific radionuclides, concentrations, and changes in activity with time. 
The suite of radionuclides that have been detected in fluid samples returned from nuclear event cavities at the NTS include: ${ }^{3} \mathrm{H},{ }^{14} \mathrm{C},{ }^{22} \mathrm{Na},{ }^{36} \mathrm{Cl},{ }^{54} \mathrm{Mn}$, ${ }^{60} \mathrm{Co},{ }^{85} \mathrm{Kr},{ }^{90} \mathrm{Sr},{ }^{99} \mathrm{Tc},{ }^{103,106} \mathrm{Ru},{ }^{125} \mathrm{Sb},{ }^{129} \mathrm{I},{ }^{134,137} \mathrm{Cs},{ }^{144} \mathrm{Ce},{ }^{152,154,155} \mathrm{Eu},{ }^{226} \mathrm{Ra}$, $235,238 \mathrm{U}$, and $238,239,240 \mathrm{Pu}$. Radioactivity was found in all cavity waters. The activity of some groundwaters was above the drinking water standard.

Fluid samples were also collected and analyzed from satellite wells located outside the test cavities. The same nuclides found in cavity waters were also found in satellite well waters although the activity of specific nuclides in near-field water samples was usually lower than measured in cavity waters. Not every nuclide was found and/or analyzed in every sample.

A list of specific radionuclides and their allowable limit in drinking water as proposed by the Environmental Protection Agency is provided in Table 3 (Federal Register, 40 CFR 141 and 142, 1991). The Federal Register (1996) section 141.16 states that if more than one man-made radionuclide is present in the groundwater, the total annual dose should not exceed $4 \mathrm{mrem} / \mathrm{y}$. These drinking water limits were calculated relative to consumption of 2 liters of water per day so to not exceed the annual dose equivalent of 4 mrem/y. The ${ }^{3} \mathrm{H}$ and ${ }^{90} \mathrm{Sr}$ limits were calculated using the revised Federal Guidance Report No. 11 (Adams, 1996). 
Table 3

\begin{tabular}{lr}
\hline Tritium $\left({ }^{3} \mathrm{H}\right)$ & $84,600 \mathrm{pCi} / \mathrm{L}$ \\
Carbon $14\left({ }^{14} \mathrm{C}\right)$ & $3,200 \mathrm{pCi} / \mathrm{L}$ \\
Sodium $22\left({ }^{22} \mathrm{Na}\right)$ & $466 \mathrm{pCi} / \mathrm{L}$ \\
Chlorine $36\left({ }^{36} \mathrm{Cl}\right)$ & $1,850 \mathrm{pCi} / \mathrm{L}$ \\
Cobalt $60\left({ }^{60} \mathrm{Co}\right)$ & $218 \mathrm{pCi} / \mathrm{L}$ \\
Strontium $90\left({ }^{90} \mathrm{Sr}\right)$ & $3.5 \mathrm{pCi} / \mathrm{L}$ \\
Technetium $99\left({ }^{99} \mathrm{Tc}\right)$ & $3,790 \mathrm{pCi} / \mathrm{L}$ \\
Ruthenium $106\left({ }^{106} \mathrm{Ru}\right)$ & $203 \mathrm{pCi} / \mathrm{L}$ \\
Antimony $125\left({ }^{125} \mathrm{Sb}\right)$ & $1,940 \mathrm{pCi} / \mathrm{L}$ \\
Iodine $129\left({ }^{129} \mathrm{I}\right)$ & $21 \mathrm{pCi} / \mathrm{L}$ \\
Cesium $137\left({ }^{137} \mathrm{Cs}\right)$ & $119 \mathrm{pCi} / \mathrm{L}$ \\
Europium $155\left({ }^{155} \mathrm{Eu}\right)$ & $3590 \mathrm{pCi} / \mathrm{L}$ \\
Radium $226\left({ }^{226} \mathrm{Ra}\right)$ & $16 \mathrm{pCi} / \mathrm{L}$ \\
Uranium $234\left({ }^{234} \mathrm{U}\right)$ & $26 \mathrm{pCi} / \mathrm{L}$ \\
Uranium $235\left({ }^{235 \mathrm{U})}\right.$ & $27 \mathrm{pCi} / \mathrm{L}$ \\
Uranium $238\left({ }^{238 \mathrm{U})}\right.$ & $26 \mathrm{pCi} / \mathrm{L}$ \\
Plutonium $238(238 \mathrm{Pu})$ & $7 \mathrm{pCi} / \mathrm{L}$ \\
Plutonium $239,240(239,240 \mathrm{Pu})$ & $65 \mathrm{pCi} / \mathrm{L}$ \\
Americium $241(241 \mathrm{Am})$ & $6 \mathrm{pCi} / \mathrm{L}$
\end{tabular}

Note: $\left(10^{12} \mathrm{pCi}=1 \mathrm{Ci}\right)$

Summarized below are results of two field experiments associated with the CAMBRIC and CHESHIRE events that frame our present understanding of radionuclide transport at the Nevada Test Site. The two examples were chosen to highlight some of what has been learned and is not meant as an exhaustive summary.

The differences in CAMBRIC and CHESHIRE events afforded an opportunity to compare radionuclide migration in two different geologic settings (See Fig. 4 for location). The CAMBRIC event was a relatively small event fired in an alluvial basin with a very low hydrologic gradient, resulting in estimated groundwater velocities at $<20 \mathrm{~m} / \mathrm{y}$ (Buddemeier et al., 1991). The CHESHIRE event was much larger and was detonated in brecciated rhyolitic volcanic rock dominated by fracture flow with a higher hydrologic gradient. Groundwater velocities were estimated at $>30 \mathrm{~m} / \mathrm{y}$ (Buddemeier et al., 1991). The experiments associated with both events have been extensively documented in the report and journal literature and the reader is encouraged to investigate these sources for a more thorough review. 


\section{CAMBRIC}

The CAMBRIC event was detonated in hole U-5e on May 14, 1965 with a yield of $0.75 \mathrm{kt}$ (Fig. 5) (Hoffman et al., 1977; Bryant, 1992 and references therein). The device was detonated at a depth of $294 \mathrm{~m}$ in alluvium, $73 \mathrm{~m}$ below the pre-shot water table. A re-entry hole, RNM-1, was drilled and water samples collected. A satellite hole, RNM-2S, was located downgradient approximately $91 \mathrm{~m}$ from the CAMBRIC cavity and screened at a depth 16-41 m below the bottom edge of the cavity.

Solid samples of melt glass and rubble were also collected from re-entry hole, RNM-1. Core samples consisting of both glass and rubble debris were dried and analyzed. Radionuclides that were detected included fission products, ${ }^{106} \mathrm{Ru},{ }^{125} \mathrm{Sb},{ }^{137} \mathrm{Cs},{ }^{144} \mathrm{Ce},{ }^{155} \mathrm{Eu}$, neutron activation products, ${ }^{54} \mathrm{Mn},{ }^{60} \mathrm{Co}$, ${ }^{134} \mathrm{Cs},{ }^{152} \mathrm{Eu},{ }^{154} \mathrm{Eu}$, and ${ }^{239} \mathrm{Pu}$ and ${ }^{241} \mathrm{Am}$. This material was graded between glass and non-glassy fraction and re-analyzed. The highest activities for all the specific radionuclides were found in the glassy fraction, although significant levels of ${ }^{90} \mathrm{Sr},{ }^{137} \mathrm{Cs}$, and ${ }^{144} \mathrm{Ce}$ were found in the unfused fraction. The refractory elements, ${ }^{147} \mathrm{Pm},{ }^{155} \mathrm{Eu},{ }^{239} \mathrm{Pu}$ and ${ }^{241} \mathrm{Am}$ were highly enriched in the melt glass.

The more volatile elements such as ${ }^{125} \mathrm{Sb}$ and fission products with gaseous precursors, e.g., ${ }^{90} \mathrm{Sr},{ }^{137} \mathrm{Cs}$ were depleted in the melt glass relative to highly refractory elements. Only about $23 \%$ of the ${ }^{90} \mathrm{Sr}$ and $7 \%$ of the ${ }^{137} \mathrm{Cs}$ relative to ${ }^{239} \mathrm{Pu}$ remain in the melt (Hoffman et al., 1977). Radionuclides that have high $R_{d}$ 's $(>1)$ are strongly partitioned to the solid phase relative to the groundwater. Distribution ratios $\left(R_{d}\right)$ between the glassy core sample and water for ${ }^{90} \mathrm{Sr},{ }^{137} \mathrm{Cs}$ and ${ }^{239} \mathrm{Pu}$ were approximately $10^{2}, 10^{4}$ and $10^{8}$, respectively.

Numerous water samples were collected and analyzed by LLNL and LANL over the course of the experiments. ${ }^{3} \mathrm{H},{ }^{36} \mathrm{Cl},{ }^{60} \mathrm{Co},{ }^{85} \mathrm{Kr},{ }^{90} \mathrm{Sr},{ }^{99} \mathrm{Tc},{ }^{106} \mathrm{Ru}$, ${ }^{125} \mathrm{Sb},{ }^{129} \mathrm{I},{ }^{137} \mathrm{Cs}$, and ${ }^{239} \mathrm{Pu}$ were detected in cavity fluids. With the exception of ${ }^{60} \mathrm{Co}$, all concentrations measured 10 years after the event were above the 1991 proposed drinking water standard.

Water samples from satellite well RNM-2S were also analyzed. Water was pumped for over two years before ${ }^{3} \mathrm{H}$ was detected. After 17 years of pumping well RNM-2S, the only radionuclides detected were ${ }^{3} \mathrm{H},{ }^{36} \mathrm{Cl}, 85 \mathrm{Kr},{ }^{99} \mathrm{Tc},{ }^{106} \mathrm{Ru}$, ${ }^{125} \mathrm{Sb}$, and ${ }^{129} \mathrm{I}$. The activities measured in waters collected from the satellite well were significantly below those of the cavity waters.

Tritium is produced in large quantities in nuclear tests (Table 1) and was the most abundant radionuclide measured in all the water samples. Unlike the 
actinides and fission products that are refractory, ${ }^{3} \mathrm{H}$ becomes incorporated in the water molecule as HTO. Results from experiments showed that greater than $95 \%$ of the residual ${ }^{3} \mathbf{H}$ forms HTO due to isotopic exchange between tritiated hydrogen gas and $\mathrm{H}_{2} \mathrm{O}$ at elevated temperatures (Hoffman et al., 1977). As noted earlier, for this reason, ${ }^{3} \mathrm{H}$ moves conservatively with groundwater.

The amount of residual ${ }^{3} \mathrm{H}$ is highly variable and depends on the specific nuclear device employed. The maximum ${ }^{3} \mathrm{H}$ values were from samples of cavity fluid collected 10 years after the CAMBRIC event and were on the order of $6 \times 10^{9} \mathrm{pCi} / \mathrm{L}$ (Bryant, 1992). After $15 \times 10^{6} \mathrm{~m}^{3}$ of water had been pumped from the cavity, the ${ }^{3} \mathrm{H}$ declined significantly to less than $10^{3} \mathrm{pCi} / \mathrm{L}$.

Tritium activities in waters collected outside the nuclear cavities tend to be lower due to dispersion. Waters collected from the satellite well, RNM-2S, had a maximum ${ }^{3} \mathrm{H}$ value of approximately $7 \times 10^{6} \mathrm{pCi} / \mathrm{L}$ (Bryant, 1992). Compared to ${ }^{3} \mathrm{H}$ concentrations measured in cavity waters, $\left(10^{9}-10^{10} \mathrm{pCi} / \mathrm{L}\right)$ near-field concentrations decrease by more than a factor of 1000 over the $\sim 100$ $\mathrm{m}$ distance between the cavity and satellite well.

In addition to ${ }^{3} \mathrm{H}$, noble gases $\left({ }^{85} \mathrm{Kr}\right)$, anionic species $\left({ }^{36} \mathrm{Cl},{ }^{99} \mathrm{Tc},{ }^{129} \mathrm{I},{ }^{106} \mathrm{Ru}\right)$ migrated at essentially the same rate as the groundwater between the cavity and the satellite well. This suggests that these species are conservative in groundwater and do not strongly interact with the surrounding rock media.

\section{CHESHIRE}

The CHESHIRE event was detonated in hole U-20n on February 14, 1976 with a yield between 200-500 kt (Fig. 6) (Buddemeier and Isherwood, 1985, Buddemeier et al., 1991, Erikson, 1991, Sawyer et al., in prep). The device was fired in brecciated rhyolite at a depth of $1167 \mathrm{~m}$ - considerably below the $630 \mathrm{~m}$ depth of the pre-event water table. A re-entry hole (U20n-PS-1ddh) was drilled and samples collected. In 1985, the re-entry hole was plugged and reperforated $250 \mathrm{~m}$ above the cavity and approximately $100 \mathrm{~m}$ outside the chimney. Water was pumped and sampled. In 1987, a satellite well, UE-20n1, was drilled approximately $300 \mathrm{~m}$ downgradient from the estimated cavity boundary.

Water samples collected from the cavity contained: ${ }^{3} \mathrm{H},{ }^{22} \mathrm{Na},{ }^{36} \mathrm{Cl},{ }^{54} \mathrm{Mn},{ }^{60} \mathrm{Co}$,

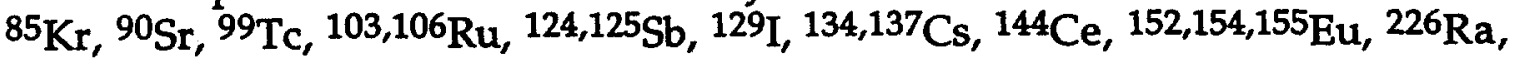
$235,238 \mathrm{U}$, and $238,239,240 \mathrm{Pu}$. The actinide, $241 \mathrm{Am}$, was detected in one study, but the measured levels were near the detection limit, making an accurate identification questionable. Tritium was measured in concentrations as high as $2 \times 10^{9} \mathrm{pCi} / \mathrm{L}$. During pumping from $1983-1985$ the decay corrected ${ }^{3} \mathrm{H}$ concentrations in the cavity samples decreased by approximately $70 \%$. In 
$1984,{ }^{3} \mathrm{H}$ concentrations were approximately $5 \times 10^{8} \mathrm{pCi} / \mathrm{L}$. Cavity samples collected in 1984 had ${ }^{125} \mathrm{Sb}$ and ${ }^{137} \mathrm{Cs}$ activity levels above the Federal drinking water standards; ${ }^{99} \mathrm{Tc}$ and ${ }^{129} \mathrm{I}$ and other detected radionuclide activities were below the drinking water standards.

${ }^{3} \mathrm{H},{ }^{36} \mathrm{Cl},{ }^{85} \mathrm{Kr},{ }^{99} \mathrm{Tc},{ }^{106} \mathrm{Ru},{ }^{125} \mathrm{Sb},{ }^{129} \mathrm{I}$, and ${ }^{137} \mathrm{Cs}$, were measured in pumped waters collected from both the plugged re-entry hole $100 \mathrm{~m}$ outside the chimney and the satellite well. ${ }^{22} \mathrm{Na},{ }^{54} \mathrm{Mn},{ }^{60} \mathrm{Co},{ }^{144} \mathrm{Ce}$, and ${ }^{152,154,155} \mathrm{Eu}$ were detected in the plugged re-entry hole waters, but not in waters collected from the satellite well. These samples represent waters from outside the cavity. In 1987 , the ${ }^{3} \mathrm{H},{ }^{99} \mathrm{Tc}$ and ${ }^{129} \mathrm{I}$ activities in the satellite samples were in the same range as measured in the cavity waters (decay corrected to 1984). In contrast, ${ }^{125} \mathrm{Sb}$ and ${ }^{137} \mathrm{Cs}$ activities were strongly retarded in samples from both outside the chimney and the satellite well. In the satellite waters ${ }^{125} \mathrm{Sb}$ and ${ }^{137} \mathrm{Cs}$ activities were only $22 \%$ and less than $1 \%$, respectively, of those measured in the cavity waters.

Concentrations of anionic species ${ }^{36} \mathrm{Cl},{ }^{99} \mathrm{Tc},{ }^{129} \mathrm{I}$ ratioed to ${ }^{3} \mathrm{H}$ were constant suggesting that these nuclides migrate with groundwater and are not attenuated during transport. These results are similar to those from the CAMBRIC experiment. In contrast to the conservative nature of ${ }^{3} \mathrm{H},{ }^{36} \mathrm{Cl}$, ${ }^{99} \mathrm{Tc}$, and ${ }^{129} \mathrm{I}$, the activities of ${ }^{125} \mathrm{Sb}$ and ${ }^{137} \mathrm{Cs}$ in the satellite well decreased compared to cavity waters. Although the concentrations of ${ }^{125} \mathrm{Sb}$ and ${ }^{137} \mathrm{Cs}$ were attenuated to a greater extent than the conservative species, they are still capable of significant transport in groundwater as evidenced by their presence in near-field waters. The activities of ${ }^{99} \mathrm{Tc},{ }^{125} \mathrm{Sb},{ }^{129} \mathrm{I}$, and ${ }^{137} \mathrm{Cs}$ measured in waters from the satellite well were all below the drinking water standards.

\section{Colloids}

Buddemeier and Hunt (1988) studied the potential of radionuclides to sorb to colloids using cavity waters collected from the re-entry hole at CHESHIRE. The colloids were collected on filters ranging between $1-0.006 \mu \mathrm{m}$. The unfiltered water, the colloids attached to the filters and the ultrafiltered water were analyzed for radionuclides. The unfiltered waters had measurable quantities of ${ }^{3} \mathrm{H},{ }^{22} \mathrm{Na},{ }^{54} \mathrm{Mn},{ }^{60} \mathrm{Co},{ }^{106} \mathrm{Ru},{ }^{125} \mathrm{Sb}, 134,137 \mathrm{Cs},{ }^{144} \mathrm{Ce}$, and $152,154,155 \mathrm{Eu}$. Most of the radionuclides ${ }^{54} \mathrm{Mn},{ }^{60} \mathrm{Co},{ }^{106} \mathrm{Ru},{ }^{144} \mathrm{Ce}$, and $152,154,155 \mathrm{Eu})$ were almost completely $(98 \%)$ sorbed on the colloids; only ${ }^{3} \mathrm{H}$ and ${ }^{22} \mathrm{Na}$ were not sorbed and remained in the ultrafiltrate. $\mathrm{Cs}$ and $\mathrm{Sb}$ were both sorbed to the colloids and dissolved in the ultrafiltrate. Five percent of the ${ }^{125} \mathrm{Sb}$ and up to 45 percent of the ${ }^{134,137} \mathrm{Cs}$ was sorbed on the colloids, with the remainder detected in the filtered water. The same results were found for water samples collected just outside the chimney area, but at reduced concentrations. 
These results demonstrate that a significant number of radionuclides found in the cavity waters are colloidally bound. Radionuclides with high sorption coefficients may be transported in groundwater as colloids.

\section{Observations of Radionuclide Migration at the NTS}

From these studies the following observations can be made:

- Conservative radionuclides, ${ }^{3} \mathrm{H},{ }^{85} \mathrm{Kr},{ }^{99} \mathrm{Tc},{ }^{106} \mathrm{Ru},{ }^{36} \mathrm{Cl}$, and ${ }^{129} \mathrm{I}$ were measured in both the cavity and the near-field water samples. ${ }^{85} \mathrm{Kr},{ }^{99} \mathrm{Tc}$, ${ }^{106} \mathrm{Ru},{ }^{36} \mathrm{Cl}$, and ${ }^{129} \mathrm{I}$ migrate at the same rate as ${ }^{3} \mathrm{H}$, suggesting that these conservative radionuclides are not attenuated by interaction with the rock media. As a result, they are ideal tracers for monitoring groundwater flow.

- During the initial pumping of the waters from satellite wells at CAMBRIC and CHESHIRE, the concentrations of the conservative anionic species ${ }^{36} \mathrm{Cl},{ }^{99} \mathrm{Tc},{ }^{129} \mathrm{I}$ were higher relative to ${ }^{3} \mathrm{H}$. The arrival of anionic species preceding ${ }^{3} \mathrm{H}$ may reflect anion exclusion effects (Buddemeier et al., 1991). These effects are minor compared to the constancy of movement of the majority of activity.

- Tritium was initially found at similar levels of activities in both cavities and behaved conservatively in both studies. In the case of CAMBRIC, the impacted water had yet to reach the satellite well, whereas at CHESHIRE breakthrough of tritiated water was detected in the downgradient well. In the CHESHIRE study, it is possible that the ${ }^{3} \mathrm{H}$ plume had already passed the satellite well accounting for the similar levels of activity measured from the satellite and cavity waters.

- The non-conservative radionuclides are strongly attenuated during transport. The nuclides ${ }^{125} \mathrm{Sb}$ and ${ }^{134,137} \mathrm{Cs}$ were measured at much lower concentrations in the CHESHIRE study, and they were not measurable in the satellite well at the CAMBRIC study.

- Colloids are an important potential agent for radionuclide transport in groundwater. The radionuclides ${ }^{54} \mathrm{Mn},{ }^{60} \mathrm{Co},{ }^{106} \mathrm{Ru},{ }^{144} \mathrm{Ce}$, and $152,154,155 \mathrm{Eu}$, were almost completely $(>98 \%)$ sorbed onto the colloidal fraction in the water samples. ${ }^{125} \mathrm{Sb}$ and ${ }^{134,137} \mathrm{Cs}$ were partially sorbed onto colloids, with a significant portion remaining dissolved in the ultrafiltered groundwater. 


\section{Summary}

The radionuclide source term is heterogeneously distributed throughout the cavity, chimney area and within several cavity radii of the working point. In general, the more volatile a radionuclide or its precursor the farther it will travel from the working point. The most refractory radionuclides are highly concentrated in the melt glass. Volatile and semi-volatile radionuclides are depleted in the melt glass relative to the refractory species and highly concentrated in the overlying rubble. The maximum extent of initial distribution of radioactivity is not well known, but minimum distances of up to 5 cavity radii vertically and approximately 3 radii horizontally for the most volatile elements have been documented.

The mobility of radionuclides in groundwater, following their release from the subsurface at a nuclear test cavity, is governed by the flow rate, groundwater chemistry, solid particles (particulates and colloids), and the geochemical behavior of individual radionuclides. The ultimate movement of radionuclides is the result of complex physiochemical processes including dissolution, precipitation, aqueous complexation, sorption and colloid formation.

Studies have shown that the majority of the radionuclides are trapped in the melt glass. The more volatile species or species with volatile precursors, such as ${ }^{90} \mathrm{Sr},{ }^{106} \mathrm{Ru},{ }^{125} \mathrm{Sb},{ }^{144} \mathrm{Ce},{ }^{137} \mathrm{Cs}$, are found concentrated in the unfused fraction. Volatile species such as the alkali metals $(\mathrm{Na}, \mathrm{K}, \mathrm{Rb})$ are also concentrated in the rubble material. The bimodal distribution of radionuclides in the subsurface complicates the release function to the groundwater.

Leaching radioactivity from melt glass and rubble matrix is a slow process. In leaching experiments, the nuclear explosive melt glass lost less than $1 \%$ of its pre-leach activity in one year, suggesting that radioactivity is gradually released. The rate of radionuclide release from the melt glass is slower than that from the matrix rubble. The difference in leach rates between glass and rock can be more than an order of magnitude (Hoffman et al., 1977).

Many experiments designed to measure the sorption of specific radionuclides under different conditions were completed. The majority of the radionuclides have high $R_{d}$ 's and should be retarded, strongly decreasing the release and transport of these radionuclides in the subsurface, as observed. Yet, because radionuclides can sorb on particulates and colloids these otherwise immobile radionuclides may migrate via colloids in groundwater. Further understanding of colloid transport is necessary in order to evaluate how this affects radionuclide migration in the near-field. 
Colloid studies at CHESHIRE demonstrate that groundwaters can carry a significant particle load both within and outside the cavity region. A substantial fraction of the total radioactivity detected in the groundwater was associated with colloids $(>0.003 \mu \mathrm{m})$. The dissolved $\left({ }^{3} \mathrm{H},{ }^{22} \mathrm{Na}\right)$, colloidally bound $\left({ }^{54} \mathrm{Mn},{ }^{60} \mathrm{Co},{ }^{106} \mathrm{Ru},{ }^{144} \mathrm{Ce}\right.$, and $\left.152,154,155 \mathrm{Eu}\right)$ and both dissolved and sorbed $\left({ }^{40} \mathrm{~K},{ }^{125} \mathrm{Sb},{ }^{134,137} \mathrm{Cs}\right)$ species are transported hydrologically through the saturated zone at the NTS. The rare earth and transition metal radionuclides are strongly bound to colloids.

It is clear from field studies that radionuclides are transported in groundwater. The most rapidly transported radionuclides in groundwater are the conservative species $\left({ }^{3} \mathrm{H},{ }^{85} \mathrm{Kr},{ }^{99} \mathrm{Tc},{ }^{106} \mathrm{Ru},{ }^{36} \mathrm{Cl}\right.$, and $\left.{ }^{129} \mathrm{I}\right)$ as they are not attenuated by interactions with the host matrix. The non-conservative radionuclides, or cationic species (e.g. ${ }^{125} \mathrm{Sb}$, and $134,137 \mathrm{Cs}$ ) are strongly attenuated during transport.

The level of activity for many of the radionuclides measured in the cavity water is in many cases above the drinking water standards. In contrast, most of the non-conservative nuclides detected in waters from outside the cavities have activity levels much lower than cavity fluids and below the drinking water standards.

A multi-faceted scientific approach has been required to address the complex nature of radionuclide contamination in the subsurface at the NTS. We have learned that the conservative elements that are dissolved as neutral species $\left({ }^{3} \mathrm{H},{ }^{85} \mathrm{Kr}\right)$ or anions $\left({ }^{36} \mathrm{Cl},{ }^{99} \mathrm{Tc},{ }^{129} \mathrm{I}\right)$ migrate at the same rate as groundwater without appreciable sorption, but our understanding of how and to what extent the other cationic radionuclides are retarded is less clear. We have learned that the majority of the residual activity after a nuclear detonation in the subsurface is trapped in the melt glass and that dissolution of the radionuclides from that glass is a slow process. Yet, we do not know the rates of dissolution or if the activity in the groundwater is colloidally bound, dissolved or will sorb to mineral surfaces. We have learned that a substantial fraction of the total radioactivity in groundwater can be associated with sorption on colloids, but we do not know the effects of long term transport. Answers to these questions are needed for geochemical modeling of the nearfield radionuclide transport.

\section{Current and Future Research}

On-going and future technical investigations listed below focus on areas critical to further characterizing the hydrologic source term. These are: 1) increasing our understanding of the spatial distribution of radionuclides in the subsurface, 2) determining the boundary conditions which control radionuclide transport, 3) characterizing the near-field hydrologic regime and 
4) modeling these processes for construction of a predictive hydrologic transport model.

- Studies at LLNL are underway to investigate radionuclide distribution between glass and rubble from a shot detonated in rhyolitic tuff, a common host rock composition at the NTS. LLNL will also evaluate the depositional behavior of specific nuclides, some of which are both matrix and surface deposited.

- It is still not known what the particulate load is for groundwater colloids at the NTS, nor is it known to what extent colloids with sorbed nuclides can be transported in different media. We do not yet know what hydrologic conditions favor colloid transport in groundwater relative to sorption to the host rock surface. These questions and others must be addressed and incorporated into modeling efforts for near-field radionuclide transport.

For this reason, LANL, in collaboration with LLNL, is currently investigating the role of colloids in radionuclide transport using impacted groundwaters collected in the near-field of the TYBO event. The TYBO satellite well cluster is located approximately $280 \mathrm{~m}$ from the working point. The TYBO satellite wells are at a greater distance from the working point than at CHESHIRE. In addition to the tritium and fission products, the TYBO near-field groundwater will also be analyzed for $\mathrm{Pu}$.

- Future characterization of groundwater from cavities and developed satellite wells in FY97 will provide much needed information on the current distribution of radionuclides in the groundwater. This work will feed into geochemical modeling of near-field transport. As a result of this need to better measure the hydrologic source term for the Nevada Test Site, water is being produced from wells adjacent to or within saturated test cavities created by the BASEBALL, INGOT, TYBO and BULLION events. Sampling and analysis of fluid samples will identify radionuclides susceptible to migration. Ultimately samples from these wells will allow determination of the controls on radionuclide release and potential downgradient transport. Remedial investigations for the Nevada Test Site rely on credible and comprehensive statements regarding the initial distribution and movement of radionuclides by groundwater.

- In order to interpret glass dissolution experiments in terms of rates and mechanisms the experiments must be fully characterized including the solution, glass and any secondary layers or mineral phases. Only then can the results be incorporated into a mechanistic model to predict long-term glass dissolution. For this reason, leaching experiments on melt glass carried out by LLNL will focus on the mechanisms of dissolution. 
- LLNL will develop a modeling framework to quantitatively evaluate the nature of the hydrologic source term for a variety of aqueous, mobile, and long-lived radionuclides in the near-field of a nuclear test. Geochemical modeling of the near-field environment will predict the transition between the radiologic and hydrologic source terms. This algorithm will also logically support predictive hydrologic transport and risk assessment models.

- Because we do not know whether nuclear test cavities in the vadose zone are contributing material to the hydrologic source terms we cannot predict the importance of the large amount of radioactive residue deposited above the water table at the NTS. Both LLNL and LANL are seeking opportunities to measure the possible movement of radionuclides around and below the tests that occurred in the vadose zone to improve our knowledge of this source term.

\section{Acknowledgments}

This report was sponsored by the Underground Test Area Operable Unit Program of DOE Nevada Operations Office (DOE-NVOO). Reviews by J. L. Thompson, D.K. Smith, C.J. Bruton, G.A. Pawloski and G.P. Murphy were appreciated. 


\section{References}

Adams, S. (1996). UGTA Subcommittee on Source Terms: Dose Evaluation for individuals ingesting radiologically contaminated groundwater. Internal memo, International Technology Corporation, p10.

Bates, J.K., Jardine, L.J., and Steindler, M.J. (1982). Hydration aging of nuclear waste glass. Science, 218:51-54.

Borg, I.Y., (1975). Radioactivity trapped in melt produced by a nuclear explosion, Nuclear Technology, 26:88-100.

Borg, I.Y., Stone, R., Levy, H.B., and Ramspott, L.D. (1976). Information pertinent to the migration of radionuclides in ground water at the Nevada Test Site. Part 1: Review and analysis of existing information. Lawrence Livermore National Laboratory, UCRL-52078.

Bourcier, W.L. (1994). Waste glass corrosion modeling: comparison with experimental results. Mat. Res. Soc. Symp. Proc., 333:69-82.

Bowen, S.M., Baca, P.L., Olivas, L.F., Geoffrion, C.G., Thompson, J.L., Miller, C.M., Goishi, W., Esser, B.K., Meadows, J.W., Namboodiri, N., Smith, D.K., and Wild, J.F. (1994). Nevada Test Site radionuclide inventory, 1955-1992 (U). Los Alamos National Laboratory, LA-CP-94-0226, 34p. SECRET-RESTRICTED DATA.

Bryant, E.A. (1992). The Cambric migration experiment. Los Alamos National Laboratory, LA-12335-MS, p37.

Buddemeier, R.W. and Hunt, J.R. (1988). Transport of colloidal contaminants in groundwater: Radionuclide migration at the Nevada Test Site, Applied Geochemistry, 3:535-548.

Buddemeier, R.W. and Isherwood, D. (1985), Radionuclide Migration Project 1984 Progress Report, Lawrence Livermore National Laboratory, UCRL$53628,71 \mathrm{p}$.

Buddemeier, R.W., Finkel, R.C., Marsh, K.V., Ruggieri, M.R., Rego, J.H., and Silva, R.J. (1991) Hydrology and radionuclide migration at the Nevada Test Site. Radiochimica Acta 52/53:275-282.

Chapman, J.B., Hershey, R.L. and Lyles, B.F. (1996). Groundwater velocities at the Nevada Test Site: ${ }^{14}$ Carbon-based estimates. Desert Research Institute, DOE/NV11508-03, UC-703 p19. 
Coles, D.G., Weed, H.C., Tewley, J.D. (1979). Geochemical studies of sorption and transport of radionulcides in rock media. Lawrence Livermore National Laboratory UCRL-52929.

Davisson, M.L., Kenneally, J.M., Smith, D.K., Hudson, G.B., Nimz, G.J. and Rego, J.H. (1994). Preliminary report on the isotope hydrology investigations at the Nevada Test Site: Hydrologic Resources Management Program. Lawrence Livermore National Laboratory UCRL-ID-116122.

DOE, see U.S. Department of Energy.

Environmental Protection Agency, (1991) National primary drinking water regulations, proposed rules. Federal Register, 40CFR Parts 141 and 142. 56:33050-33127.

Environmental Protection Agency, (1996) National primary drinking water regulations, proposed rules. Federal Register, 40CFR Parts 141. 132:101192.

Erikson, S.J. (1991). Report of drilling and radionuclide migration invesigations at UE20n\#1, Pahute Mesa, Nevada Test Site, 1987. Desert Research Institute, DOE/NV 10384-35, UC-703 p118.

Failor, R.A., Coles, D.G., and Rego, J.H. (1983). A leaching study of nuclear melt glass: part I. Lawrence Livermore National Laboratory UCRL-ID19729,71p.

Federal Register, see Environmental Protection Agency.

Goishi., W., Esser, B.K., Meadows, J., Namboodiri, N., Smith, D. K., Wild, J., Bowen, S., Baca, P., Olivas, L., Geoffrion, C., Thompson, J. and Miller, C. (1994). Total radionuclide inventory associated with underground nuclear tests conducted at the Nevada Test Site 1955 - 1992 (U), Los Alamos National Laboratory, LA-CP-94-0222, 242p, SECRET RESTRICTED DATA.

Hoffman, D.C., Stone, R., and Dudley, W.W., Jr. (1977). Radioactivity in the underground environment of the Cambric nuclear explosion at the Nevada Test Site. Los Alamos National Laboratory, LA-6877-MS

Hudson, B.C., Jones, E.M., Keller, C.E. and Smith, C.W. (1981) Cavity radius uncertainties. In: Proceedings of the Monterey Containment Symposium, Monterey CA. Los Alamos National Laboratory, LA9211-C vol 1.413p. 
Laczniak, R.J., Cole, J.C., Sawyer, D.A., and Trudeau, D.A. (1996). Summary of hydrogeologic controls on ground-water flow at the Nevada Test Site, Nye Country, Nevada. United States Geological Survey Professional Paper, Water Resources Investigations Report 96-4109 p59.

Nimz, G.J. and Thompson, J.L. (1992). Underground radionuclide migration at the Nevada Test Site, U.S. Department of Energy, Nevada Field Office, DOE/NV-346, UC-703, 17p.

Office of Technology Assessment, see U.S. Congress.

Ramspott, L.D., Tewhey, J.D., Coles, D.G., Weed, H.C., Schweiger, J.S., Stone, R. (1979). FY78 annual technical report of Lawrence Livermore Laboratory's participation in the DOE-NV project: radionuclide migration in the ground. Lawrence Livermore National Laboratory UCRL-18259-78, 29p.

Rawson, S.A., Walton, J.C., and Baca, R.G. (1991). Migration of actinides from a transuranic waste disposal site in the vadose zone. Radiochimica Acta 52/53:447-486.

Sawyer, D.A., Thompson, J.L. and Smith, D.K. (in prep.) The Cheshire experiment. Los Alamos National Laboratory,

Silva, R.J. and Nitsche, H. (1995). Actinide Environmental Chemistry. Radiochimica Acta 70/71:377-396.

Smith, D.K., (1993). A review of literature pertaining to the leaching and sorption of radionuclides associated with nuclear explosive melt glasses. Lawrence Livermore National Laboratory UCRL-ID-113370, p26.

Smith, D.K., (1995a). Characterization of Nuclear Explosive Melt Debris, Radiochimica Acta, 69:157 - 167.

Smith, D.K., (1995b). Challenges in defining a radionuclide and hydrologic source term for underground nuclear test centers, Nevada Test Site, Nye County, NV. Lawrence Livermore National Laboratory, UCRL-JC120389, 10p.

Smith, D.K., (1995c). Phenomenology of underground nuclear explosions conducted at the Nevada Test Site with emphasis on recent experience at Baseball (U7ba) and Ingot (U2gg). Lawrence Livermore National Laboratory 20p. 
Smith, D.K., Esser, B.K. and Thompson, J.L. (1995). Uncertainties associated with the definition of a hydrologic source term for the Nevada Test Site, Lawrence Livermore National Laboratory, UCRL-ID-120322, 21p.

Smith, D.K., Esser, B.K., Kenneally, J.M., Nagle, R.J., Rego, J.H., Royval, J.L. (1996). Hydrologic Resources Management Program FY 1995 progress report. Lawrence Livermore National Laboratory, UCRL-ID-123486.

Smith, D.K. and Thompson, J.L. (1996). Investigation of the occurrence of gaseous fission products and tritium in cores returned from the HYRAX U-3bh event chimney, Area 3 radiological waste management site. In: Hydrogeologic characterization of U-3bh collapse zone. Appendix F. Bechtel Nevada.

Thompson, J.L., (1996) Radionuclide distribution in a nuclear test cavity: the Baseball event. Radiochimica Acta, 72:157-162.

Thompson, J.L. and Gilmore, J.S. (1991). Migration of fission products at the Nevada Test Site: Detection with an isotopic tracer. Radiochimica Acta, 52/53:229-231.

U.S. Congress, Office of Technology Assessment, (1989). The Containment of Underground Explosions, OTA-ISC-414, Washington, DC, U.S. Government Printing Office, 80p.

U.S. Department of Energy, (1994). United States Nuclear Tests, July 1945September 1992. U.S. Government Printing Office DOE/NV-209 (Rev. 13) $38 \mathrm{p}$.

Winograd, I.J. and Thordarson, W. (1975). Hydrogeologic and hydrochemical framework, South-Central Great Basin, Nevada-California, with special reference to the Nevada Test Site, United States Geological Survey Professional Paper 712-C, 126p.

Wolfsberg, K. (1978). Sorption-desorption studies of Nevada Test Site alluvium and leaching studies of nuclear test debris. Los Alamos National Laboratory, LA-7216-MS, 32p. 


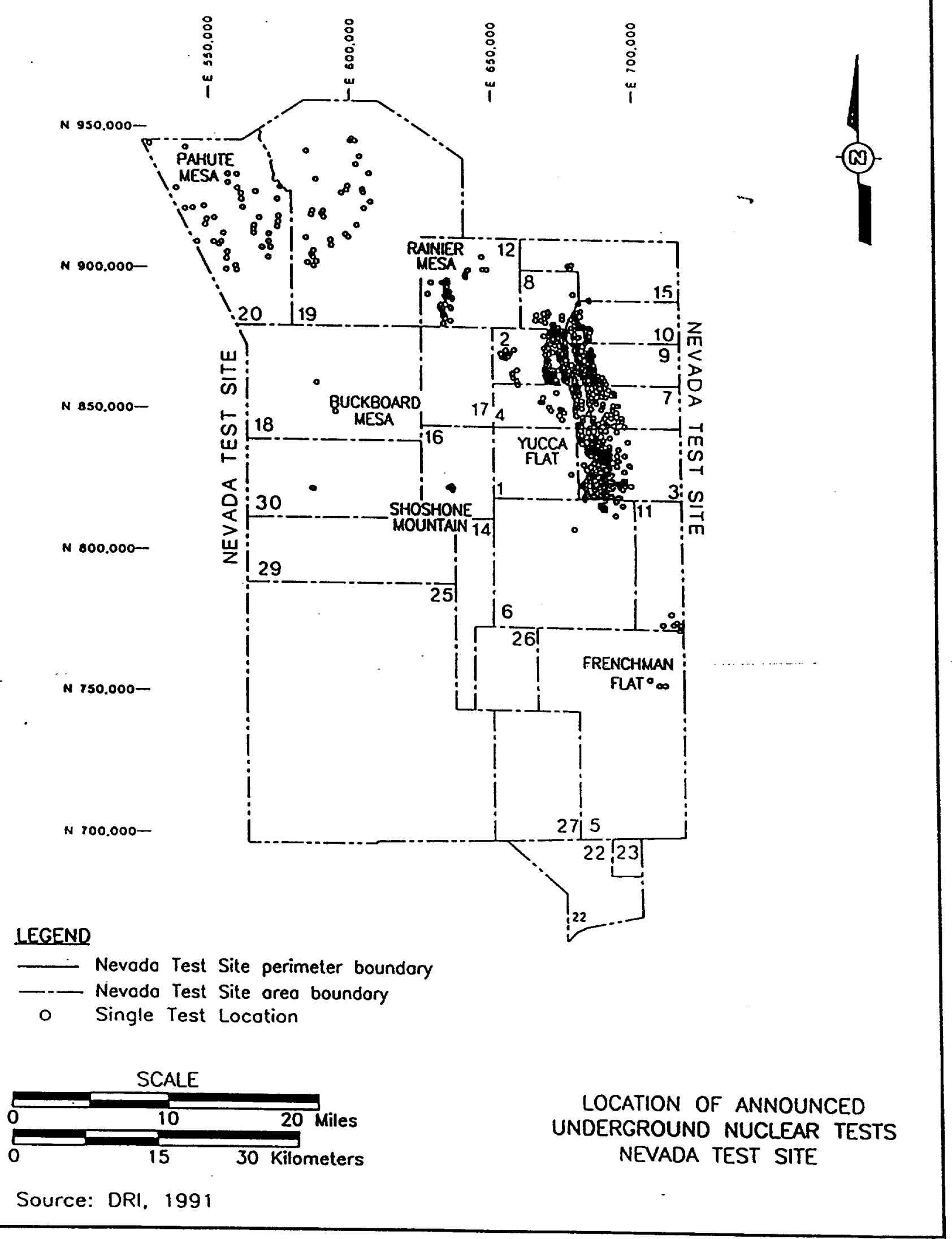

Figure 1 
z ว.เกริง

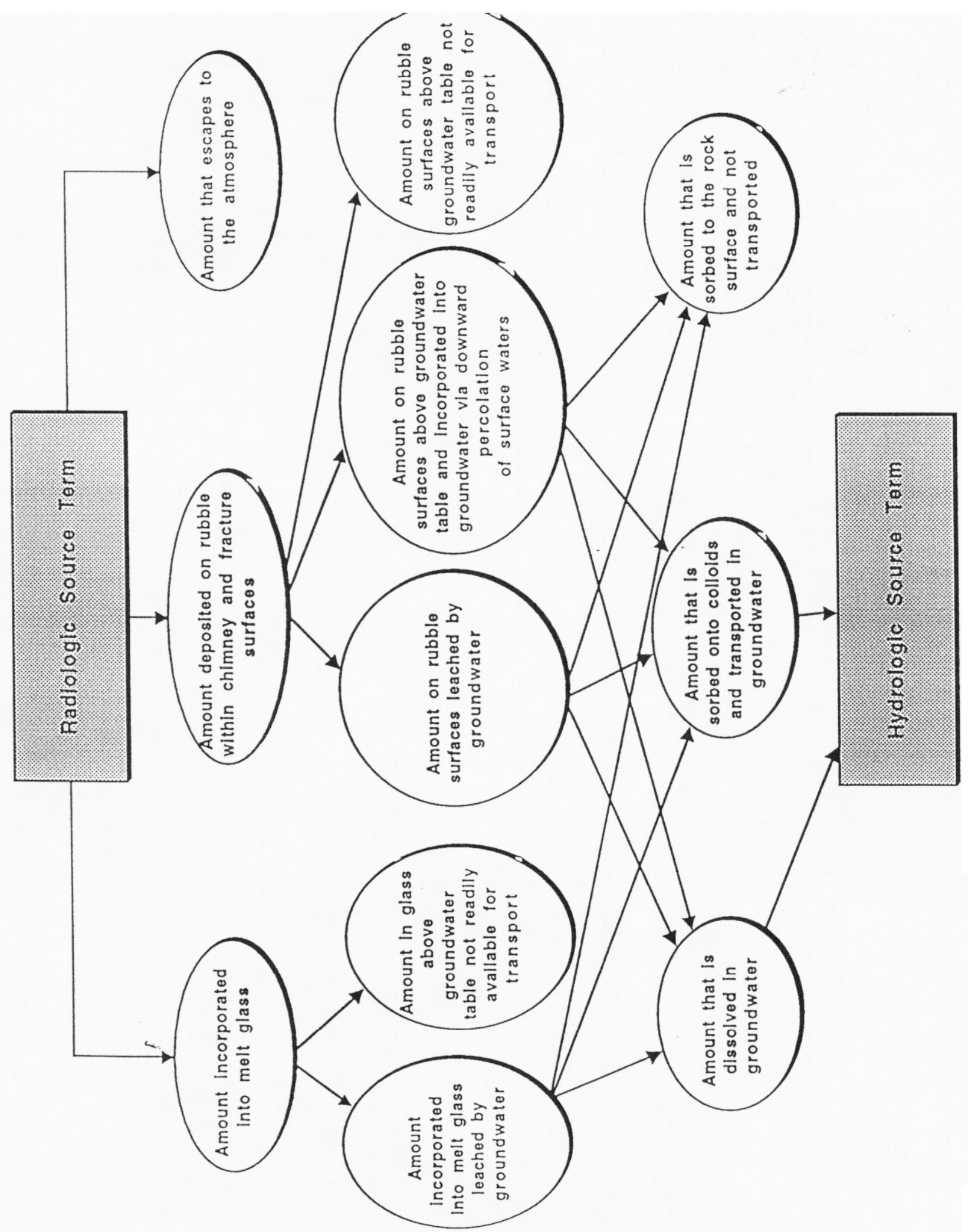

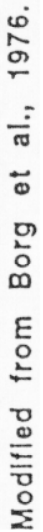


Nevada Test Site Radionuclide Inventory-Below Water Table

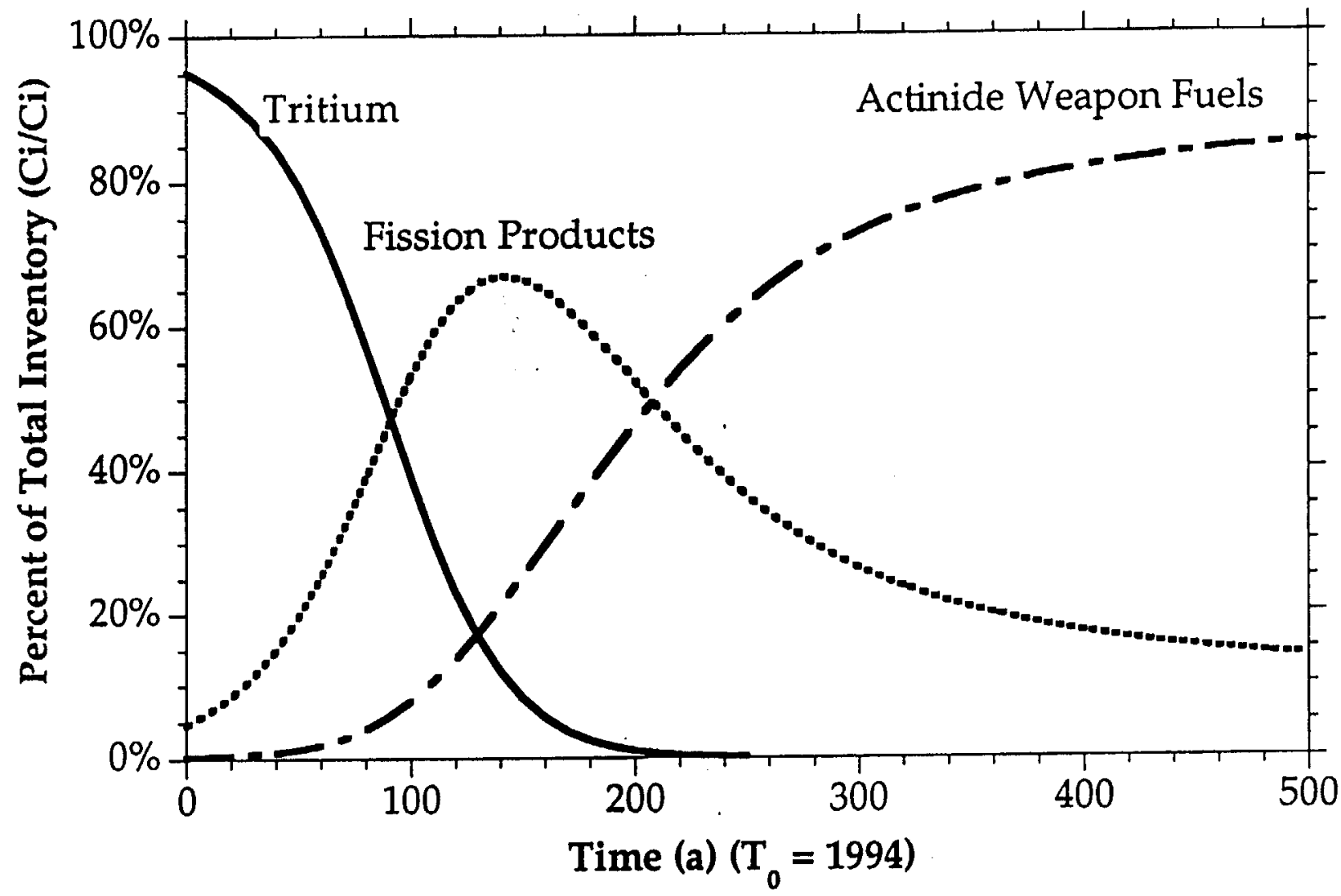




\section{Location of Underground Nuclear. Test Events with Saturated Cavities Available for Sampling}

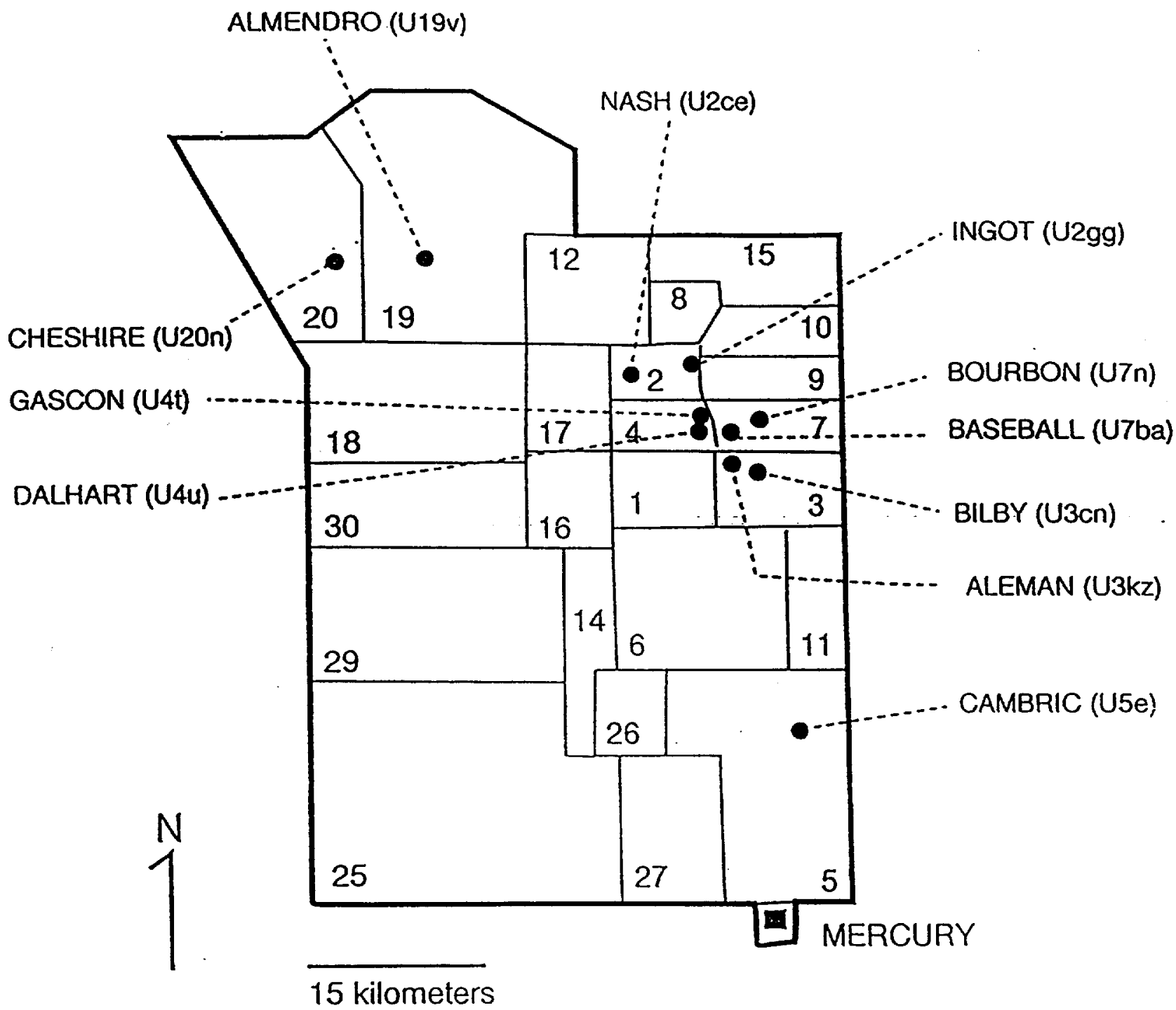

Figure 4 


\section{Cross Section of Cambric Study Area}



Modified from Hoffman et al., 1977

Figure 5 


\section{Cross Section of Cheshire Study Area}

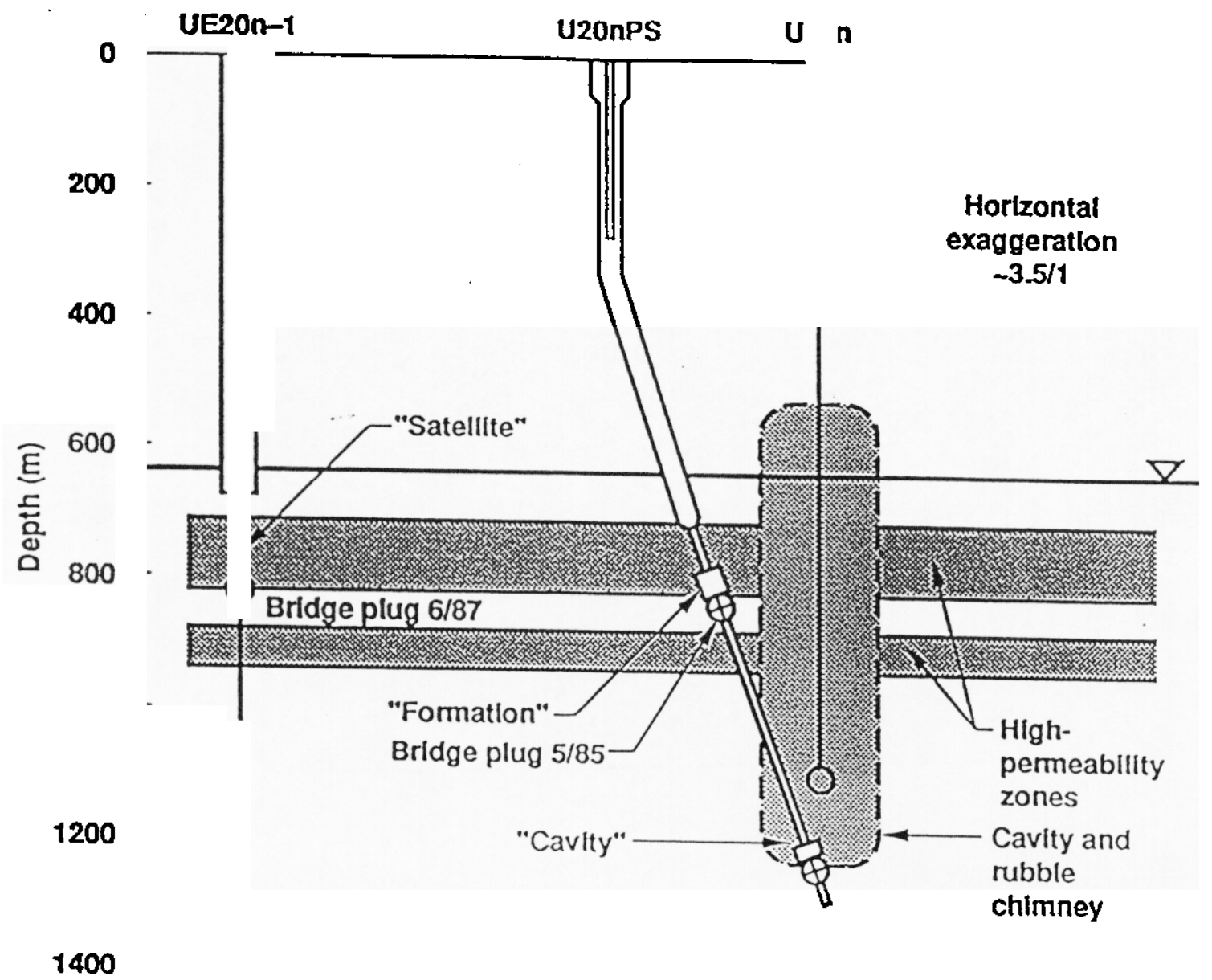

Modified from Buddemeier et al., 1991

Figure 6 


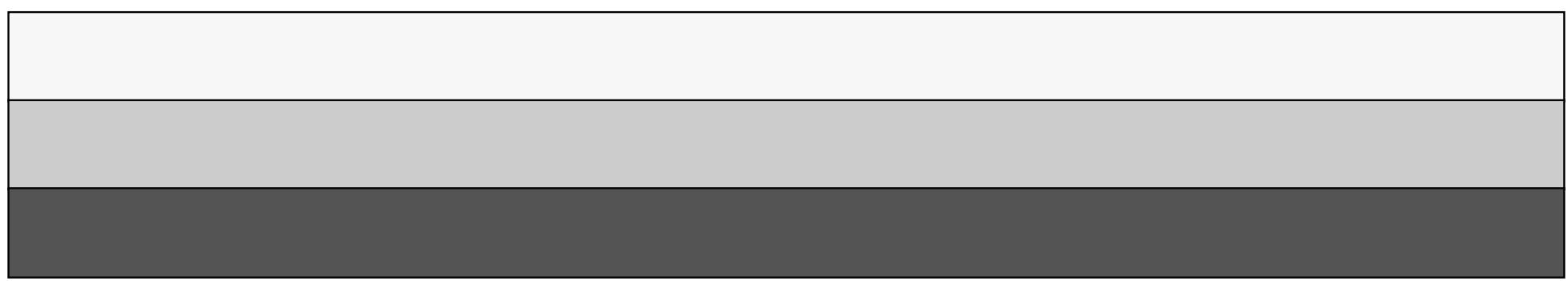

